\title{
Cytokines, cortisol, and nitric oxide as salivary biomarkers in oral lichen planus: a systematic review
}

Janaina Silva Martins HUMBERTO(a) Jefferson Veronezi PAVANIN(b) Maria José Alves da ROCHA(a) Ana Carolina Fragoso MOTTA ${ }^{(b)}$

(a) Universidade de São Paulo - USP, School of Dentistry of Ribeirão Preto, Department of Morphology, Physiology, and Basic Pathology, Ribeirão Preto, SP, Brazil.

(b) Universidade de São Paulo - USP, School of Dentistry of Ribeirão Preto, Department of Stomatology, Ribeirão Preto, SP, Brazil

Declaration of Interest: The authors certify that they have no commercial or associative interest that represents a conflict of interest in connection with the manuscript.

\section{Corresponding Author:}

Ana Carolina Fragoso Motta

E-mail: anacfm@usp.br

hitps://doi.org/10.1590/1807-3107bor-2018.vol32.0082

Submitted: January 12, 2018

Accepted for publication: May 05, 2018

Last revision: July 04, 2018
Abstract: The etiopathogenesis of oral lichen planus (OLP) is still not fully elucidated, and it is believed that its development could involve a neuro-immune-endocrine profile. This systematic review investigated the relationship between cytokines, cortisol, and nitric oxide (NO) in the saliva of OLP patients. An electronic search was conducted in Pubmed/Medline, Scopus, LIVIVO, and Web of Science databases with no restriction of language to identify studies published up to December 2017. Data extraction was performed using the Preferred Reporting Items for Systematic Review and Meta-Analyses (PRISMA) guidelines. A total of 140 articles were retrieved, and 32 articles fulfilled the inclusion criteria (cytokines $=17$; cortisol $=9 ; \mathrm{NO}=6$ ). The most studied cytokines in the saliva of OLP patients were interleukins IL-4, IL-6, IL-8, IFN-Y, and TNF- $\alpha$, which were higher in OLP patients than in healthy controls (HC). Salivary cortisol was found to be higher in OLP than in HC in most (55.5\%) of the selected studies, and all studies related to NO found higher levels of this marker in OLP than in HC. Despite controversial results, our review suggests that OLP patients have an increased inflammatory response, as indicated by the proinflammatory profile of salivary cytokines. In addition, we conclude that salivary cytokine and NO measurements may have significant diagnostic and prognostic potential for monitoring disease activity and therapeutic responses in OLP.

Keywords: Lichen Planus, Oral; Saliva; Biomarkers.

\section{Introduction}

Oral lichen planus (OLP) is a chronic inflammatory disease of unknown etiology with an estimated prevalence of around 0.1 to $2 \%$ worldwide that mainly affects middle-aged and elderly women. ${ }^{1,2,3,4,5,6,7}$ Currently, the disease has been clinically classified as reticular/plaque, erythematous/erosive, or ulcerative forms, and more than one clinical type may occur in the same patient. ${ }^{8}$ The classic manifestation of the disease is a reticular white line pattern (Wickham striae), with a bilateral and symmetrical presentation, and an asymptomatic course. ${ }^{3,9,10,11}$ The etiopathogenesis is still unknown, but it is accepted that development of the lesions is related to a $\mathrm{T}$ cell response against epithelial cells as a result of different types of stimuli, including medications as well as genetic and psychological factors. ${ }^{8,12,13}$ 
In recent decades, studies focusing on identifying biomarkers involved in OLP pathogenesis have been developed using different types of tissues and fluids. ${ }^{14,15}$ In particular, easy and noninvasive collection, high sensitivity, and good correlation with tissues and serum assays in the screening of oral diseases make the evaluation of whole saliva helpful in the study of OLP. ${ }^{16,17,18}$ Among the biomarkers for OLP, measuring salivary cytokines could be a potential tool for diagnosis, prognosis, disease response, and therapeutic target discovery. ${ }^{14,19,20,21}$ Additionally, the determination of serum and/or salivary hormones, including cortisol, a well-known biomarker of chronic stress and anxiety, and nitric oxide (NO), one of the most important cytotoxic mediators of activated immune cells, may help to clarify the relationship between psychological disorders and OLP development. $13,22,23,24,25,26,27,28$

In the literature, different results are reported regarding the relationship between OLP and psychological disorders, cytokines or cortisol, and only a few studies report on NO levels in OLP. ${ }^{26,29,30,31}$ Considering that NO, cytokines, and cortisol have oxidative, inflammatory, and immunological properties and can be secreted in the saliva, while the association between them is unknown, we aimed to present current knowledge about the neuro-immune-endocrine profile of OLP. This review covers four topics: (a) the association between salivary cytokines and the development and progression of OLP; (b) the association between salivary cortisol and the development of OLP; (c) the association between salivary NO and the development of OLP; and (d) the association between all of these substances (cytokines, cortisol, and NO) in the saliva and the development of OLP.

\section{Methodology}

A systematic literature review was carried out based on the systematic review protocol of Khan and coworkers, ${ }^{32}$ using the Preferred Reporting Items for Systematic Review and Meta-Analyses (PRISMA) guidelines, ${ }^{33}$ which were adapted to this review.

\section{Research questions and keywords definition}

This review covered four questions: $a$. is there an association between OLP and salivary cytokine levels, and can these predict the prognosis and therapeutic response?; $b$. Is there an association between OLP and salivary cortisol levels related to psychological disorders?; c. Is there an association between OLP and salivary NO levels?; and d. Is there any relationship between OLP and cytokine, cortisol, and NO levels in saliva? The keywords selected for each question were as follows: a. "cytokine, saliva, and oral lichen planus," b. "cortisol, saliva, and oral lichen planus," c. "nitric oxide, saliva, and oral lichen planus," and d. "cytokine, cortisol, nitric oxide, saliva, and oral lichen planus."

\section{Literature search and identification of studies}

The literature search was performed in the PubMed, Scopus, LIVIVO, Web of Science, and Cochrane Library databases, to identify studies published up to December 2017 using the chosen keywords. Additional articles were retrieved by manual searches on the reference lists of the selected articles. There was no restriction of language and type of study, except for animal studies; randomized control trials (RCT), cross-sectional, case-control, and cohort studies, case series, systematic reviews, reviews, opinions, and editorials were included. Studies comparing salivary markers in OLP with other oral mucosal lesions were included only if there was a healthy control group and the comparison with OLP could be retrieved.

\section{Selection of studies}

The identified studies were scrutinized, and full-text publications that met the predefined inclusion criteria were selected. Independent reviewers (JSMH and ACFM) reviewed these manuscripts and made the final decisions regarding inclusion or exclusion. Any disagreements were resolved by consensus or arbitration with a third reviewer (MJAR). From all selected publications, metadata [author(s), year of publication, country], number of patients (cases of OLP and healthy controls), patient age, study design, type of biomarkers, and main conclusions were assessed. 


\section{Studies level of evidence}

Each article was assigned a level of evidence and grade of recommendation, and categorized according to the Oxford Center for Evidence-Based Medicine (OCEBM), which rates level of evidence among ten levels - level 1a (systematic review of randomized control trials), level $1 \mathrm{~b}$ (randomized control trials), level 1c (all or none outcome related), level 2a (systematic review of cohort studies), level $2 b$ (individual cohort studies), level 2c (outcomes research or ecological studies), level 3a (systematic review of case-control studies), level 3b (individual case-control studies), level 4 (case series), and level 5 (expert opinion). Recommendations were graded from A to D based on these levels of evidence. ${ }^{34}$

\section{Results}

\section{Study selection}

Initially, 140 studies were retrieved from searches in the five electronic databases. After removing duplicates, 47 studies remained. Twenty-nine papers were found as addressing our first question. Of these, twelve studies were excluded because they were related to treatment for lichenoid dysplasia, frequency of OLP in patients with type 2 diabetes mellitus, samples overlapping with a previous study, or not related to the scope of our study. The search regarding our second question resulted in 10 articles; one was excluded because it was a xerostomia-related review. The third question search retrieved eight studies; two were excluded, one because it was related to oral lichenoid lesions, and the other analyzed only healthy people. No study was found addressing the fourth question. An evaluation of titles and abstracts of full papers resulted in the exclusion of 15 publications. A total of 32 studies met the eligibility criteria and were retained for the final qualitative analysis. A diagram of the search process and publications selection is shown in Figure 1.

\section{Study characteristics and synthesis of results}

\section{Cytokines and OLP}

Seventeen studies reported the relationship between salivary cytokines and OLP patients (Table 1). In the clinical studies, 809 patients were evaluated

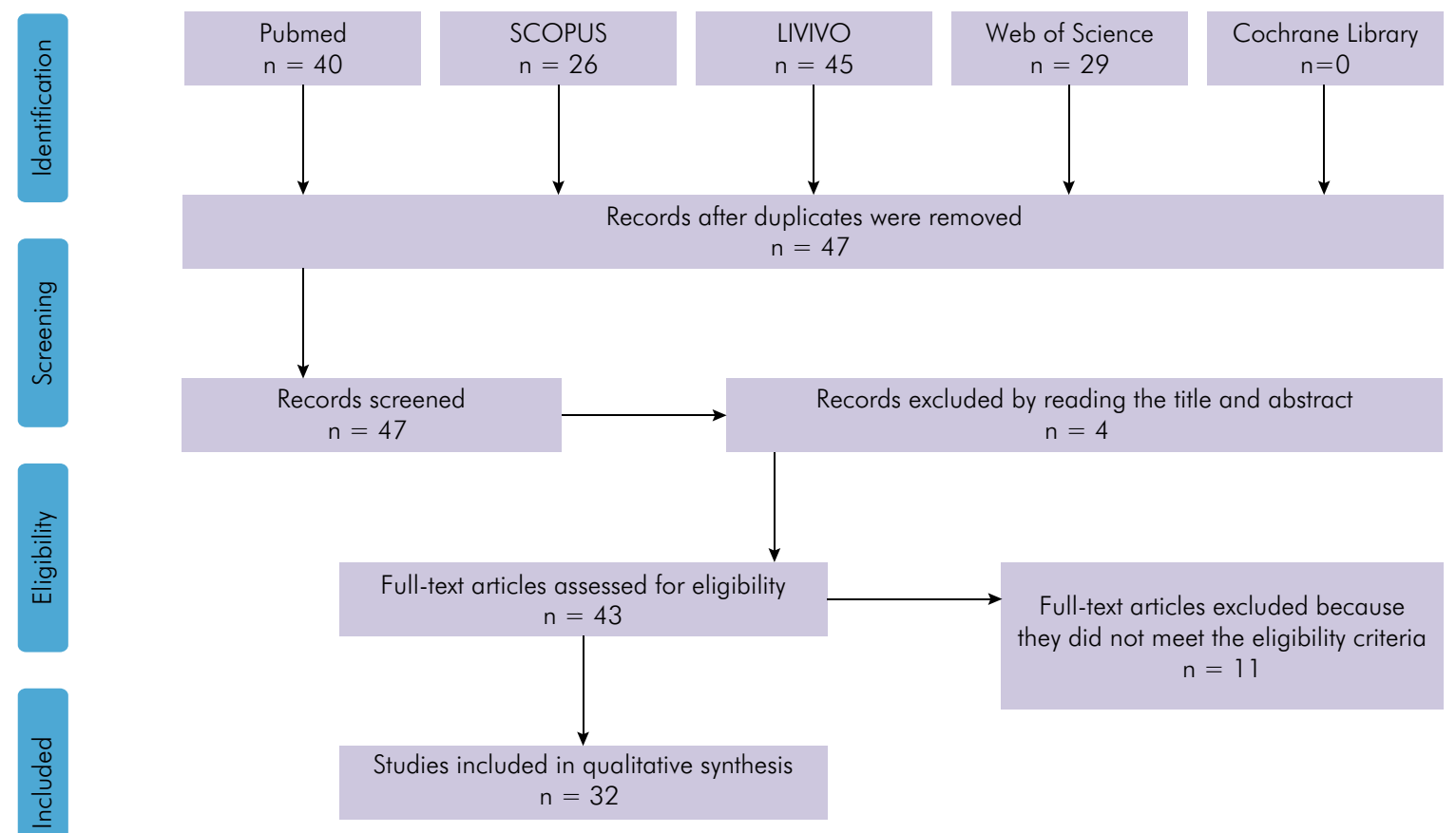

Figure 1. PRISMA flowchart of the literature search. 
Cytokines, cortisol, and nitric oxide as salivary biomarkers in oral lichen planus: a systematic review

Table 1. Summary of salivary cytokines studies in OLP patients.

\begin{tabular}{|c|c|c|c|c|c|c|c|}
\hline Studies & Cytokines & Study design & $\begin{array}{l}\text { Number of } \\
\text { patients/ } \\
\text { studies }\end{array}$ & Method & Main results & $\begin{array}{l}\text { Level of } \\
\text { evidence }\end{array}$ & $\begin{array}{l}\text { Grade of } \\
\text { recommendation }\end{array}$ \\
\hline $\begin{array}{l}\text { Pezeli-Ribaric } \\
\text { et al. }(2004)^{40}\end{array}$ & TNF- $\alpha$ & $\begin{array}{l}\text { Case-control } \\
\text { study }\end{array}$ & $\begin{array}{c}40 \mathrm{OLP} / 20 \\
\mathrm{HC}\end{array}$ & ELISA & $\begin{array}{l}\text { Salivary TNF- } \alpha \text { levels were higher in } \\
\text { OLP than in } \mathrm{HC} \text { and showed positive } \\
\text { correlation with the clinical form: } \\
\text { higher levels in erosive/ulcerative than } \\
\text { in reticular form. }\end{array}$ & $3 b$ & B \\
\hline $\begin{array}{l}\text { Rhodus et al. } \\
(2005 b)^{15}\end{array}$ & $\begin{array}{l}\text { TNF- } \alpha, I L-1 \alpha \\
\text { IL- } 6 \text {, and IL- } 8\end{array}$ & $\begin{array}{l}\text { Case-control } \\
\text { study }\end{array}$ & $\begin{array}{c}13 \mathrm{OLP} / 13 \\
\mathrm{HC}\end{array}$ & ELISA & $\begin{array}{l}\text { Higher salivary TNF- } \alpha, \mid \mathrm{IL}-1 \alpha, \mathrm{IL}-6 \text {, and } \\
\text { IL-8 levels in OLP than in HC. }\end{array}$ & $3 b$ & B \\
\hline $\begin{array}{l}\text { Rhodus et al. } \\
(2006)^{20}\end{array}$ & $\begin{array}{l}\text { TNF- } \alpha, \text { IL- } 1 \alpha \\
\text { IL- } 6 \text {, and IL- } 8\end{array}$ & $\begin{array}{l}\text { Open non- } \\
\text { randomized } \\
\text { trial }\end{array}$ & $\begin{array}{c}13 \mathrm{OLP} / 13 \\
\mathrm{HC}\end{array}$ & ELISA & $\begin{array}{l}\text { Lower salivary TNF- } \alpha, \text { IL- } 1 \alpha, \text { IL-6, and } \\
\text { IL-8 levels after topical dexamethasone } \\
\text { compared with baseline. }\end{array}$ & $2 c$ & B \\
\hline $\begin{array}{l}\text { Tao et al. } \\
(2008)^{42}\end{array}$ & IL-4 and IFN-y & $\begin{array}{l}\text { Case-control } \\
\text { study }\end{array}$ & $\begin{array}{l}19 \mathrm{OLP}(10 \\
\mathrm{eOLP} \text { and } 9 \\
\mathrm{rOLP}) / 7 \mathrm{HC}\end{array}$ & ELISA & $\begin{array}{l}\text { Higher salivary IFN-y levels in eOLP } \\
\text { compared to HC. No differences for IL-4. }\end{array}$ & $3 b$ & B \\
\hline $\begin{array}{l}\text { Zhang et al. } \\
(2008)^{56}\end{array}$ & $\begin{array}{l}\text { TNF- } \alpha, \text { IL- } 6 \text {, and } \\
\text { IL-8 }\end{array}$ & $\begin{array}{l}\text { Case-control } \\
\text { study }\end{array}$ & $\begin{array}{l}30 \mathrm{OLP}(16 \\
\mathrm{eOLP} \text { and } 14 \\
\mathrm{rOLP}) / 30 \mathrm{HC}\end{array}$ & ELISA & $\begin{array}{l}\text { Higher salivary TNF- } \alpha, \text { IL- } 6 \text {, and IL- } 8 \\
\text { levels in OLP compared to HC, either } \\
\text { between the RT form or the ES form } \\
\text { with the HC, separately. }\end{array}$ & $3 b$ & B \\
\hline $\begin{array}{l}\text { Liv et al. } \\
(2009)^{4}\end{array}$ & IL-4 and IFN-y & $\begin{array}{l}\text { Case-control } \\
\text { study }\end{array}$ & $\begin{array}{l}79 \text { OLP }(58 \\
\text { eOLP and } 21 \\
\mathrm{rOLP}) / 41 \mathrm{HC}\end{array}$ & ELISA & $\begin{array}{l}\text { Lower IFN- } \gamma \text { and higher IL-4 levels in } \\
\text { saliva of OLP than in } \mathrm{HC} \text {, respectively; } \\
\text { IL-4 higher in eOLP than in rOLP form. }\end{array}$ & $3 b$ & B \\
\hline $\begin{array}{l}\text { Ghallab et al. } \\
(2010)^{21}\end{array}$ & $\begin{array}{l}\text { IFN- } \gamma, \text { TNF- } \alpha \text {, } \\
\text { and sTNFR-2 }\end{array}$ & $\begin{array}{l}\text { Open non- } \\
\text { randomized } \\
\text { trial }\end{array}$ & $\begin{array}{c}20 \mathrm{OLP} / 20 \\
\mathrm{HC}\end{array}$ & ELISA & $\begin{array}{l}\text { Higher salivary IFN-y, TNF- } \alpha \text {, and } \\
\text { sTNFR-2 levels in OLP at baseline } \\
\text { compared to HC and } \\
\text { after treatment with prednisone. }\end{array}$ & $2 c$ & B \\
\hline $\begin{array}{l}\text { Dan et al. } \\
(2011)^{35}\end{array}$ & IL-10 and IFN-y & $\begin{array}{c}\text { Case-control } \\
\text { study }\end{array}$ & $\begin{array}{l}79 \text { OLP }(58 \\
\text { eOLP and } 21 \\
\mathrm{rOLP}) / 41 \mathrm{HC}\end{array}$ & ELISA & $\begin{array}{l}\text { Higher salivary IL-10 levels and lower } \\
\text { IFN-y in OLP than in HC. No significant } \\
\text { difference of salivary cytokines levels } \\
\text { between erythematous and reticular form. }\end{array}$ & $3 b$ & B \\
\hline $\begin{array}{l}\text { Zhang et al. } \\
(2012)^{36}\end{array}$ & IL-18 & $\begin{array}{l}\text { Case-control } \\
\text { study }\end{array}$ & $\begin{array}{c}103 \mathrm{OLP} / 48 \\
\mathrm{HC}\end{array}$ & ELISA & $\begin{array}{l}\text { Higher salivary IL- } 18 \text { levels in } \\
\text { OLP than in HC. }\end{array}$ & $3 b$ & B \\
\hline $\begin{array}{l}\text { Cheng et al. } \\
(2014)^{55}\end{array}$ & IL-6 and IL-8 & $\begin{array}{l}\text { Case-control } \\
\text { study }\end{array}$ & $\begin{array}{c}18 \text { OSCC/20 } \\
\mathrm{CP} / 21 \\
\mathrm{aOLP} / 20 \\
\mathrm{iOLP} / 21 \mathrm{HC}\end{array}$ & ELISA & $\begin{array}{l}\text { Highest salivary IL- } 6 \text { and IL- } 8 \text { levels in } \\
\text { OSCC; higher salivary IL-6 and IL- } 8 \text { in } \\
\text { aOLP than in CP and HC. }\end{array}$ & $3 b$ & B \\
\hline $\begin{array}{l}\text { Abdel-Haq } \\
\text { et al. }(2014)^{41}\end{array}$ & IL-6 & $\begin{array}{c}\text { Case-control } \\
\text { study }\end{array}$ & $\begin{array}{c}46 \mathrm{OLP} / 10 \\
\mathrm{CLP} / 16 \mathrm{OLP} \\
+\mathrm{CLP} / 56 \mathrm{HC}\end{array}$ & ELISA & $\begin{array}{c}\text { Salivary IL-6 levels were higher in OLP } \\
\text { than in } \mathrm{HC} \text {, especially in atrophic- } \\
\text { erosive form. }\end{array}$ & $3 b$ & B \\
\hline $\begin{array}{l}\text { Liv et al. } \\
(2014)^{39}\end{array}$ & IFN- $\alpha$, IL-4 & $\begin{array}{l}\text { Case-control } \\
\text { study }\end{array}$ & $60 \mathrm{OLP} / 40 \mathrm{HC}$ & ELISA & $\begin{array}{l}\text { Higher IL-4 levels and } \\
\text { low IFN- } \alpha \text { in OLP patients. }\end{array}$ & $3 b$ & B \\
\hline $\begin{array}{l}\text { Lu et al. } \\
(2015)^{19}\end{array}$ & $\begin{array}{l}\text { IL- } 1, \text { IL-2, IL-4, IL- } \\
5, \text { IL-6, IL-8, IL-10, } \\
\text { IL- } 12, \text { IL-17, IL- } \\
18, \text { IFN- } \gamma, \text { TGF- } \beta \text {, } \\
\text { and TNF- } \alpha\end{array}$ & $\begin{array}{l}\text { Literature } \\
\text { review }\end{array}$ & 145 studies & Miscellaneous & $\begin{array}{l}\text { High salivary IL-1, IL-6, IL-18 and } \\
\text { TNF- } \alpha \text { levels in OLP patients. }\end{array}$ & 5 & D \\
\hline $\begin{array}{l}\text { Wang et al. } \\
(2015)^{37}\end{array}$ & IL-17 and IL-23 & $\begin{array}{l}\text { Case-control } \\
\text { study }\end{array}$ & $\begin{array}{c}30 \mathrm{OLP} / 15 \\
\mathrm{HC}\end{array}$ & ELISA & $\begin{array}{l}\text { Higher salivary IL- } 17 \text { levels in OLP than } \\
\text { in HC. No differences for IL-23. }\end{array}$ & $3 b$ & B \\
\hline $\begin{array}{l}\text { Malakzadeh } \\
(2015)^{38}\end{array}$ & IFN- $\gamma$ and IL-4 & $\begin{array}{l}\text { Case-control } \\
\text { study }\end{array}$ & $63 \mathrm{OLP} / 63 \mathrm{HC}$ & ELISA & $\begin{array}{l}\text { Higher salivary IL-4 and } \\
\text { IFN- } \gamma \text { in OLP than in HC }\end{array}$ & $3 b$ & B \\
\hline $\begin{array}{l}\text { Jeong et al. } \\
(2016)^{43}\end{array}$ & IL- $1 \mathrm{~b}$ and IL-8 & $\begin{array}{l}\text { Open non- } \\
\text { randomized } \\
\text { trial }\end{array}$ & $\begin{array}{c}21 \mathrm{OLP} / 30 \\
\mathrm{HC}\end{array}$ & ELISA & $\begin{array}{l}\text { High levels of IL- } 1 \mathrm{~b} \text { and IL- } 8 \text { in OLP } \\
\text { than in HC; No changes of salivary } \\
\text { IL- } 1 \mathrm{~b} \text { and IL-8 levels after topical } \\
\text { sulfasalazine compared to baseline. }\end{array}$ & $2 c$ & B \\
\hline $\begin{array}{l}\text { Mozaffari et al. } \\
(2017)^{44}\end{array}$ & TNF- $\alpha$ & $\begin{array}{l}\text { Systematic } \\
\text { review }\end{array}$ & 7 studies & Miscellane & s Higher salivary TNF- $\alpha$ in OLP than HC & $3 a$ & B \\
\hline
\end{tabular}

OLP: oral lichen planus; HC: Healthy controls; eOLP: Erythematous/ulcerative form; rOLP: Reticular form; OSCC: Oral squamous cell carcinoma; CP: Chronic periodontitis; aOLP: Active OLP; iOLP: Inactive OLP; CLP: Cutaneous LP. 
(540 women and 269 men) with a mean age of 58 (range 21-76). These clinical studies analyzed whole unstimulated saliva (WUS) through ELISA. 14,35,36,37,38,39 In addition, three studies showed an association of cytokine concentration with the clinical form, ${ }^{4,40,41,42}$ and three studies evaluated the impact of steroid or anti-inflammatory therapy for OLP on salivary concentrations of proinflammatory cytokines. ${ }^{20,21,43}$

The overall analysis of these studies showed that OLP patients have higher salivary levels of IL-6, IL-8, IL-17, IL-18, IFN- $Y$, and TNF- $\alpha$ than healthy controls. $\mathrm{Lu}$ and coworkers reviewed the current knowledge on the involvement of inflammatory cytokines in OLP, including salivary concentrations of proinflammatory, anti-inflammatory, and regulatory cytokines, and found that IL-1, IL-6, IL-8, IL-18, and TNF- $\alpha$ are increased in the saliva of OLP patients..$^{19}$ In addition, three studies showed an association of cytokine concentration with the clinical form: Pezelj-Ribaric and coworkers showed higher levels of TNF- $\alpha$ in erosive/ulcerative OLP than in reticular lesions; Liu and coworkers found higher levels of IL-4 in ulcerative than in reticular lesions; and AbdelHaq and coworkers found higher IL-6 levels in erosive than in reticular lesions. ${ }^{4,40,41}$ Moreover, Mozaffari and coworkers suggested that the measurement of TNF- $\alpha$ in saliva of OLP patients may be more useful than that in serum for diagnostic and therapeutic purposes. ${ }^{44}$ Regarding the impact of steroid therapy on salivary cytokine concentrations, topical $0.1 \%$ dexamethasone mouthwash reduced the salivary levels of TNF- $\alpha$, IL- $1 \alpha$, IL-6, and IL-8 after 6 weeks of treatment. ${ }^{20}$ Ghallab and coworkers found a significant reduction in salivary IFN-y, TNF- $\alpha$, and sTNFR-2 levels after treatment with systemic prednisone (40-60 mg/day; no more than 60 days), suggesting that salivary cytokines could help monitor the therapeutic response in OLP. ${ }^{21}$

\section{Cortisol and OLP}

We found nine studies on salivary cortisol in OLP patients (Table 2). Two hundred and fifty four

Table 2. Summary of publications on salivary cortisol studies in OLP patients.

\begin{tabular}{|c|c|c|c|c|c|c|}
\hline Studies & Study design & Number of patients & Method & Main findings & $\begin{array}{l}\text { Level of } \\
\text { evidence }\end{array}$ & $\begin{array}{l}\text { Grade of } \\
\text { recommendation }\end{array}$ \\
\hline $\begin{array}{l}\text { Rodstrom } \\
\text { et al. }(2001)^{45}\end{array}$ & $\begin{array}{l}\text { Case-control } \\
\text { study }\end{array}$ & $10 \mathrm{OLP} / 10 \mathrm{HC}$ & RIA & $\begin{array}{l}\text { No difference for salivary cortisol levels was found } \\
\text { between } \mathrm{OLP} \text { and } \mathrm{HC} \text {; highest concentrations of } \\
\text { salivary cortisol in early morning. }\end{array}$ & $3 b$ & B \\
\hline $\begin{array}{l}\text { Koray et al. } \\
(2003)^{13}\end{array}$ & $\begin{array}{l}\text { Case-control } \\
\text { study }\end{array}$ & $40 \mathrm{OLP} / 40 \mathrm{HC}$ & ELISA & $\begin{array}{l}\text { Higher salivary cortisol levels } \\
\text { in OLP than in } \mathrm{HC} \text {. }\end{array}$ & $3 b$ & B \\
\hline $\begin{array}{l}\text { Shah et al. } \\
(2009)^{47}\end{array}$ & $\begin{array}{l}\text { Case-control } \\
\text { study }\end{array}$ & $30 \mathrm{OLP} / 30 \mathrm{HC}$ & ELISA & $\begin{array}{l}\text { Higher salivary cortisol levels in } 56.6 \%(17 / 30) \text { of } \\
\text { OLP patients, and there was positive correlation } \\
\text { between level of depression and cortisol }\end{array}$ & $3 b$ & B \\
\hline $\begin{array}{l}\text { Girardi et al. } \\
(2011)^{46}\end{array}$ & $\begin{array}{l}\text { Case-control } \\
\text { study }\end{array}$ & $31 \mathrm{OLP} / 31 \mathrm{HC}$ & RIA & $\begin{array}{l}\text { No difference was found } \\
\text { between OLP and HC. }\end{array}$ & $3 b$ & B \\
\hline $\begin{array}{l}\text { Nosratzehi } \\
\text { et al. }(2014)^{50}\end{array}$ & $\begin{array}{c}\text { Case-control } \\
\text { study }\end{array}$ & $20 \mathrm{OLP} / 20 \mathrm{HC}$ & ELISA & $\begin{array}{l}\text { No difference was found } \\
\text { between OLP and HC }\end{array}$ & $3 b$ & B \\
\hline $\begin{array}{l}\text { Nadendla } \\
\text { et al. }(2014)^{48}\end{array}$ & $\begin{array}{c}\text { Cross- } \\
\text { sectional } \\
\text { study }\end{array}$ & $20 \mathrm{OLP} / 20 \mathrm{HC}$ & ELISA & $\begin{array}{l}\text { Higher salivary cortisol levels } \\
\text { in OLP patients than in HC. }\end{array}$ & $2 b$ & B \\
\hline $\begin{array}{l}\text { Pippi et al. } \\
(2016)^{27}\end{array}$ & $\begin{array}{l}\text { Case-control } \\
\text { study }\end{array}$ & $20 \mathrm{OLP} / 14 \mathrm{HC}$ & ELISA & $\begin{array}{l}\text { Lower salivary cortisol levels than healthy } \\
\text { controls, and hypocortisolism in the morning. }\end{array}$ & $3 b$ & B \\
\hline $\begin{array}{l}\text { Lopez-Jornet } \\
\text { et al. }(2016)^{28}\end{array}$ & $\begin{array}{c}\text { Cross- } \\
\text { sectional } \\
\text { study }\end{array}$ & $33 \mathrm{OLP} / 32 \mathrm{HC}$ & CLIA & Higher salivary cortisol levels than $\mathrm{HC}$. & $2 b$ & B \\
\hline $\begin{array}{l}\text { Karthikeyan } \\
\text { and Aswath } \\
(2016)^{49}\end{array}$ & $\begin{array}{l}\text { Case-control } \\
\text { study }\end{array}$ & $\begin{array}{c}30 \mathrm{RAS} / 30 \mathrm{OLP} / 30 \\
\mathrm{HC}\end{array}$ & ECLIA & $\begin{array}{c}\text { Higher salivary cortisol levels in RAS and OLP } \\
\text { than in HC. }\end{array}$ & $3 b$ & B \\
\hline
\end{tabular}

OLP: oral lichen planus; RAS: Recurrent aphthous stomatitis. 
patients, most of them female, with an age range of 10 to 40 years, and a mean age of 47.2 years were evaluated. Five studies analyzed WUS and four analyzed stimulated saliva. Saliva was collected once in the morning in six studies (range: 9-12 a.m.), whereas in three other studies the authors performed multiple collections. ${ }^{27,45,46}$ Different methods were used to detect cortisol in saliva: five studies used ELISA, two used CLIA, and the other two used RIA. ${ }^{33,27,28,45,46,47,48,49}$ The correlation between salivary cortisol levels and anxiety and/or stress was determined in eight studies using different scales, such as the Beck Anxiety Inventory (BAI), Beck Depression Inventory (BDI), SCL-90, Lipp's Inventory Stress Symptoms for Adults (LISS), StaitTrait Anxiety Inventory (STAI), Hospital Anxiety and Depression Scale (HADD and HADA), Hamilton's Rating Scale for Anxiety (HAM-A), Mood Adjective Check List (MACL), and Depression, Anxiety, and Stress Scale (DASS). ${ }^{13,47,48}$ Besides salivary cortisol and anxiety/stress scales, Lopez-Jornet and coworkers used the Pittsburgh Sleep Quality Index (PSQI) and the Epworth Sleepiness Scale (ESS) to assess sleepiness in OLP patients and healthy controls. ${ }^{28}$

Five studies revealed high salivary cortisol levels in OLP patients compared to healthy controls, and in two studies the salivary cortisol levels were lower in OLP patients than in healthy controls, especially in the early morning. ${ }^{13,28,46,47,48,49}$ Three studies showed a positive correlation between salivary cortisol levels and depression, anxiety and/or stress symptoms. ${ }^{13,47,48}$ Finally, sleepiness scores were worse for OLP patients than for healthy controls. ${ }^{28}$

\section{NO and OLP}

We reviewed six studies on salivary NO in OLP patients (Table 3). All of them were case-control studies, and 131 patients were evaluated (mostly females), with an age range of 20 to 73 years. All studies analyzed saliva through the Griess method. ${ }^{26,29,30,31,51,52}$ Besides WUS, one study evaluated unstimulated gland saliva from the submandibular and parotid glands. ${ }^{51}$ Finally, one study investigated depression, anxiety, and stress state by using DASS. ${ }^{26}$

All studies analyzed in this review found higher salivary NO concentrations in OLP patients than in healthy controls, suggesting a possible association between NO production and the disease. ${ }^{52}$ Two studies showed evidence for a higher NO concentration in erosive than in non-erosive OLP. ${ }^{30,31}$ Finally, no correlation of salivary NO concentration with depression state was found in OLP patients. ${ }^{26}$

Table 3. Summary of publications on salivary NO studies in OLP patients.

\begin{tabular}{|c|c|c|c|c|c|c|}
\hline Study & $\begin{array}{c}\text { Study } \\
\text { design/level } \\
\text { of evidence }\end{array}$ & Number of patients & Method & Main findings & $\begin{array}{l}\text { Level of } \\
\text { evidence }\end{array}$ & $\begin{array}{l}\text { Grade of } \\
\text { recommendation }\end{array}$ \\
\hline $\begin{array}{l}\text { Ohashi et al. } \\
(1999)^{51}\end{array}$ & $\begin{array}{l}\text { Case-control } \\
\text { study }\end{array}$ & $\begin{array}{c}21 \mathrm{OLP} / 18 \mathrm{RAU} / 18 \\
\mathrm{HC}\end{array}$ & Griess & $\begin{array}{c}\text { Higher salivary NO levels in OLP } \\
\text { and RAU than in } \mathrm{HC} \text {. }\end{array}$ & $3 b$ & B \\
\hline $\begin{array}{l}\text { Sunitha and } \\
\text { Shanmugam } \\
(2006)^{30}\end{array}$ & $\begin{array}{l}\text { Case-control } \\
\text { study }\end{array}$ & $\begin{array}{c}20 \mathrm{OLP} / 20 \mathrm{RAU} / 20 \\
\mathrm{HC}\end{array}$ & Griess & $\begin{array}{c}\text { Higher salivary NO levels in OLP } \\
\text { and RAU than in HC. }\end{array}$ & $3 b$ & B \\
\hline $\begin{array}{l}\text { Japtap and } \\
\text { Baad }(2012)^{31}\end{array}$ & $\begin{array}{l}\text { Case-control } \\
\text { study }\end{array}$ & $\begin{array}{c}20 \mathrm{RAU} / 15 \mathrm{OLP} / 30 \\
\mathrm{HC}\end{array}$ & Griess & $\begin{array}{c}\text { Higher salivary NO levels in OLP } \\
\text { than in RAU and } H C \text {. }\end{array}$ & $3 b$ & B \\
\hline $\begin{array}{l}\text { Kapoor et al. } \\
(2013)^{26}\end{array}$ & $\begin{array}{l}\text { Case-control } \\
\text { study }\end{array}$ & $25 \mathrm{OLP} / 25 \mathrm{HC}$ & Griess & $\begin{array}{c}\text { Higher salivary NO levels in OLP } \\
\text { than in } \mathrm{HC} \text {. }\end{array}$ & $3 b$ & B \\
\hline $\begin{array}{l}\text { Panjwani } \\
\text { et al. }(2013)^{29}\end{array}$ & $\begin{array}{l}\text { Case-control } \\
\text { study }\end{array}$ & $30 \mathrm{OLP} / 30 \mathrm{HC}$ & Griess & $\begin{array}{l}\text { Higher salivary } \mathrm{NO} \text { levels in OLP } \\
\text { than in } \mathrm{HC} \text {. }\end{array}$ & $3 b$ & B \\
\hline $\begin{array}{l}\text { Tvarijonaviciute } \\
\text { et al. }(2017)^{52}\end{array}$ & $\begin{array}{l}\text { Case-control } \\
\text { study }\end{array}$ & $20 \mathrm{OLP} / 31 \mathrm{HC}$ & Griess & $\begin{array}{c}\text { Higher salivary NO level and nitrite in OLP } \\
\text { than } \mathrm{HC} \text {. }\end{array}$ & $3 b$ & B \\
\hline
\end{tabular}

NO: Nitric oxide; OLP: oral lichen planus; RAU: Recurrent aphthous ulcers; HC: healthy control. 


\section{Levels of evidence}

Tables 1 to 3 show the level of evidence and grades of recommendation for all included studies. On average, the selected studies were considered as having a low level of evidence and weak grade of recommendation, since most of them were case-control studies (level 3b/grade B). Studies related to salivary cytokines were mostly case-control studies $(n=11)$, two were open non-randomized clinical trials, and one was a review. The salivary cortisol search also included two cross-sectional studies, and six were case-control studies. All studies related to salivary NO and OLP were case-control studies.

\section{Discussion}

The present systematic review focused on the current knowledge about the neuro-immuneendocrine profile of OLP based on the perspective that cellular immunity-mediated mechanisms and/or neuroendocrine dysregulation could act as factors precipitating OLP. Furthermore, the possibility of detecting such mediators in saliva could be helpful for diagnosis, prognosis, and response of OLP patients, as well as for the discovery of therapeutic targets. It is widely known that neuroendocrine mechanisms may be mediated either centrally (HPA axis) or by the independent cutaneous neuroendocrine axis. ${ }^{53,54}$ Psychological stresses could exacerbate or precipitate cutaneous LP through neuroendocrine and neuroimmunologic mechanisms. In this context, it is worth relating the cutaneous $\mathrm{LP}$ with OLP, considering that we reviewed the association between cytokines, cortisol, and NO in the saliva of OLP patients.

The most studied cytokines in the saliva of OLP patients were interleukins IL-4, IL-6, IL-8, IFN-Y, and TNF- $\alpha$, which were higher in OLP patients than in healthy controls. Moreover, three studies found an association between salivary cytokine concentration and the clinical form of OLP, with higher levels of IL-4, IL-6, and TNF- $\alpha$ in erosive/ulcerative lesions than in reticular lesions. ${ }^{4,40,41}$ The higher salivary IL-6 levels in patients with erosive OLP seem to reflect local production by keratinocytes, monocytes, activated T lymphocytes, endothelial cells, macrophages, and fibroblasts. ${ }^{14,55}$ Additionally, the levels of this cytokine are also used to monitor the use of glucocorticoids, disease activity, and prognosis since it is correlated with a malignant transformation of OLP. There is evidence that in malignancy, IL-6 can act as an autocrine growth factor, inducing B-cell and cytotoxic cell differentiation. ${ }^{14}$ Considering the close relationship between chronic inflammation and oncogenesis, the permanent presence of high salivary levels of proinflammatory cytokines suggests that they can be important mediators of cancer development. Moreover, it is known that they are activators of apoptotic and non-apoptotic signaling cascades implicated in the onset and progression of the disease. ${ }^{4,19,56,57}$

It has been suggested that psychological alterations can modify and cause dysregulation of immune functions, such as changing the balance of Th1/ Th2 cytokines and increasing the Th2 response, which, in turn, is associated with the development of autoimmune diseases. ${ }^{58}$ In a research involving a psychoneuroimmune approach to OLP, Prolo and coworkers showed that peripheral blood $\mathrm{T}$ cells obtained from subjects with OLP revealed blunted responses to T-cell-specific mitogenic stimulation and decreased expression of IL-2 and IFN- $\gamma .{ }^{59}$ Additionally, these authors showed high levels of morning plasma cortisol and low $\mathrm{CD}^{+} \mathrm{T}$ cells in OLP patients, especially those with erosive lesions, suggesting a neuro-immune-endocrine relationship in OLP.

Although we have found contradictory results for salivary cortisol in OLP patients, most of the studies in this review $(5 / 9 ; 55.5 \%)$ showed higher salivary cortisol levels than in healthy controls. ${ }^{13,28,47,48,49}$ Additionally, two studies found a positive correlation between salivary cortisol levels and anxiety, depression or stress. ${ }^{47,48}$ A comparison of the data in the reported articles is limited by differences, including diagnostic criteria for OLP, sample size, and methods used for salivary cortisol analysis. Clements, ${ }^{60}$ in an excellent review of salivary cortisol measurement in developmental research, highlighted that any methodology used for cortisol analysis should take into consideration the time of cortisol collection, presence/absence of stressors, and the number of samples. In the current review, different collection times, sample sizes, and methods of analysis were 
used. Therefore, if there is a relationship between OLP and salivary cortisol, it still needs to be demonstrated by controlled studies with standardized methodology.

A role of $\mathrm{NO}$ as a mediator in the etiopathogenesis of OLP has been suggested by only a few studies. ${ }^{26,}$ ${ }^{51}$ Among the many functions of this gas, its action as an endothelial-derived relaxing factor, inhibitor of platelet aggregation and adhesion as well as a neuronal messenger is worthy of note. Moreover, it is a cytotoxic molecule that influences the ability of cells to kill bacteria, viruses, and protozoans as well as tumor cells, raising the possibility of its participation in OLP pathogenesis. ${ }^{51,61}$ In the immune system, NO seems to have proinflammatory and/or antiinflammatory effects, as previously demonstrated in studies related to rheumatoid arthritis, periodontal disease, diabetes, hepatitis C, Chagas disease, and bronchial asthma. ${ }^{62,63}$ All included studies reported an increase of salivary NO in OLP patients, which hypothetically results from increased levels of IL-6, TNF- $\alpha$ or IL1- $\beta$ produced by T lymphocytes and macrophages. ${ }^{26,29}$ Regarding the detection method of salivary NO, the Griess assay was the method used in the studies included in this review. ${ }^{26,29,30,31,51,52}$

In conclusion, we found controversial results for salivary cytokine and cortisol concentrations, which can be explained by differences in the clinical form, stages, and progression of OLP in the included studies, and also by the several methods used for sample analysis. Despite these inconsistent results, our review suggests that OLP patients have an increased inflammatory response, confirmed by the proinflammatory profile of salivary cytokines. Salivary NO seems to be a promising marker for studies about pathogenesis of OLP. To the best of our knowledge, this is the first review investigating the use of saliva as a model of determining the neuroimmune-endocrine profile of OLP, including the relationship between salivary cytokines, cortisol, and NO. Our review suggests that salivary cytokine and NO levels may have significant diagnostic and prognostic potential for monitoring disease activity and therapeutic responses in OLP. This study had several limitations, including the low level of evidence and recommendation of the selected studies and lack of a fully comprehensive meta-analysis. In addition, the adoption of more stringent inclusion criteria and the assessment of heterogeneity of the studies would have increased the quality of this review. Nonetheless, our analysis suggest trends in the expression of these markers in saliva that need to be confirmed by further longitudinal controlled clinical studies with larger sample sizes.

\section{Acknowledgments}

This review was supported by the São Paulo Research Foundation -FAPESP (Grants \#: 2014/11883-3 and 2015/22183-5). JSMH was supported by a postdoctoral fellowship from the School of Dentistry of Ribeirao Preto, University of Sao Paulo.

\section{References}

1. Epstein JB, Wan LS, Gorsky M, Zhang L. Oral lichen planus: progress in understanding its malignant potential and the implications for clinical management. Oral Surg Oral Med Oral Pathol Oral Radiol Endod. 2003 Jul;96(1):32-7. https://doi.org/10.1016/S1079-2104(03)00161-6

2. Lodi G, Scully C, Carrozzo M, Griffiths M, Sugerman PB, Thongprasom K. Current controversies in oral lichen planus: report of an international consensus meeting. Part 2. Clinical management and malignant transformation. Oral Surg Oral Med Oral Pathol Oral Radiol Endod. 2005 Aug;100(2):164-78. https://doi.org/10.1016/j.tripleo.2004.06.076

3. Ingafou M, Leao JC, Porter SR, Scully C. Oral lichen planus: a retrospective study of 690 British patients. Oral Dis. 2006 Sep;12(5):463-8. https://doi.org/10.1111/j.1601-0825.2005.01221.x

4. Liu W, Dan H, Wang Z, Jiang L, Zhou Y, Zhao M et al. IFNgamma and IL- 4 in saliva of patients with oral lichen planus: a study in an ethnic Chinese population. Inflammation. 2009 Jun;32(3):176-81. https://doi.org/10.1007/s10753-009-9118-2

5. Fitzpatrick SG, Hirsch SA, Gordon SC. The malignant transformation of oral lichen planus and oral lichenoid lesions: a systematic review. J Am Dent Assoc. 2014 Jan;145(1):45-56. https://doi.org/10.14219/jada.2013.10

6. Thongprasom K. Oral lichen planus: challenge and management. Oral Dis. 2018 Mar;24(1-2):172-3. https://doi.org/10.1111/odi.12712 
7. Lauritano D, Arrica M, Lucchese A, Valente M, Pannone G, Lajolo $C$ et al. Oral lichen planus clinical characteristics in Italian patients: a retrospective analysis. Head Face Med. 2016 Apr;12(1):18. https://doi.org/10.1186/s13005-016-0115-z

8. Wang J, Waal I. Disease scoring systems for oral lichen planus; a critical appraisal. Med Oral Patol Oral Cir Bucal. 2015 Mar;20(2):e199-204. https://doi.org/10.4317/medoral.20524

9. Waal I. Oral lichen planus and oral lichenoid lesions; a critical appraisal with emphasis on the diagnostic aspects. Med Oral Patol Oral Cir Bucal. 2009 Jul;14(7):E310-4.

10. Au J, Patel D, Campbell JH. Oral lichen planus [vii.]. Oral Maxillofac Surg Clin North Am. 2013 Feb;25(1):93-100. https://doi.org/10.1016/i.coms.2012.11.007

11. Gobbo M, Rupel K, Zoi V, Perinetti G, Ottaviani G, Di Lenarda $\mathrm{R}$ et al. Scoring systems for Oral Lichen Planus used by differently experienced raters. Med Oral Patol Oral Cir Bucal. 2017 Sep;22(5):e562-71.

12. Al-Hashimi I, Schifter M, Lockhart PB, Wray D, Brennan M, Migliorati CA et al. Oral lichen planus and oral lichenoid lesions: diagnostic and therapeutic considerations. Oral Surg Oral Med Oral Pathol Oral Radiol Endod. 2007 Mar;103 Suppl: S25 e112. https://doi.org/10.1016/i.tripleo.2006.11.001

13. Koray M, Dülger $\mathrm{O}, \mathrm{Ak} G$, Horasanli S, Uçok A, Tanyeri $\mathrm{H}$ et al. The evaluation of anxiety and salivary cortisol levels in patients with oral lichen planus. Oral Dis. $2003 \mathrm{Nov} ; 9(6): 298-301$. https://doi.org/10.1034/j.1601-0825.2003.00960.x

14. Rhodus NL, Cheng B, Myers S, Bowles W, Ho V, Ondrey F. A comparison of the pro-inflammatory, NF-kappaB-dependent cytokines: TNF-alpha, IL-1-alpha, IL-6, and IL-8 in different oral fluids from oral lichen planus patients. Clin Immunol. 2005 Mar;114(3):278-83. https://doi.org/10.1016/i.clim.2004.12.003

15. Rhodus NL, Cheng B, Myers S, Miller L, Ho V, Ondrey F. The feasibility of monitoring NF-kappaB associated cytokines: TNF-alpha, IL-lalpha, IL-6, and IL-8 in whole saliva for the malignant transformation of oral lichen planus. Mol Carcinog. 2005 Oct;44(2):77-82. https://doi.org/10.1002/mc.20113

16. Kaufman E, Lamster IB. The diagnostic applications of saliva: a review. Crit Rev Oral Biol Med. 2002;13(2):197-212. https://doi.org/10.1177/154411130201300209

17. Al-Tarawneh SK, Border MB, Dibble CF, Bencharit S. Defining salivary biomarkers using mass spectrometry-based proteomics: a systematic review. OMICS. 2011 Jun;15(6):353-XX. https://doi.org/10.1089/omi.2010.0134

18. Pfaffe T, Cooper-White J, Beyerlein P, Kostner K, Punyadeera C. Diagnostic potential of saliva: current state and future applications. Clin Chem. 2011 May;57(5):675-87. https://doi.org/10.1373/clinchem.2010.153767

19. Lu R, Zhang J, Sun W, Du G, Zhou G. Inflammation-related cytokines in oral lichen planus: an overview. J Oral Pathol Med. 2015 Jan;44(1):1-14. https://doi.org/10.1111/jop.12142

20. Rhodus NL, Cheng B, Bowles W, Myers S, Miller L, Ondrey F. Proinflammatory cytokine levels in saliva before and after treatment of (erosive) oral lichen planus with dexamethasone. Oral Dis. 2006 Mar;12(2):112-6. https://doi.org/10.1111/j.1601-0825.2005.01165.x

21. Ghallab NA, el-Wakeel N, Shaker OG. Levels of salivary IFN-gamma, TNF-alfa, and TNF receptor-2 as prognostic markers in (erosive) oral lichen planus. Mediators Inflamm. 2010;2010:847632. https://doi.org/10.1155/2010/847632

22. Rojo-Moreno JL, Bagán JV, Rojo-Moreno J, Donat JS, Milián MA, Jiménez Y. Psychologic factors and oral lichen planus: a psychometric evaluation of 100 cases. Oral Surg Oral Med Oral Pathol Oral Radiol Endod. 1998 Dec;86(6):687-91. https://doi.org/10.1016/S1079-2104(98)90205-0

23. Chaudhary S. Psychosocial stressors in oral lichen planus. Aust Dent J. 2004 Dec;49(4):192-5. https://doi.org/10.1111/j.1834-7819.2004.tb00072.x

24. Lundqvist EN, Wahlin YB, Bergdahl M, Bergdahl J. Psychological health in patients with genital and oral erosive lichen planus. J Eur Acad Dermatol Venereol. 2006 Jul;20(6):661-6. https://doi.org/10.1111/j.1468-3083.2006.01559.x

25. Niedbala W, Cai B, Liew FY. Role of nitric oxide in the regulation of T cell functions. Ann Rheum Dis. 2006 Nov;65 Suppl 3:iii37-40. https://doi.org/10.1136/ard.2006.058446

26. Kapoor C, Wadhwan V, Vaidya S, Malik S. Triology of nitric oxide, mast cell and stress in pathogenesis of oral lichen planus. J Oral Maxillofac Pathol. 2013 May;17(2):156-62. https://doi.org/10.4103/0973-029X.119741

27. Pippi R, Romeo U, Santoro M, Del Vecchio A, Scully C, Petti $S$. Psychological disorders and oral lichen planus: matched case-control study and literature review. Oral Dis. 2016 Apr;22(3):226-34. https://doi.org/10.1111/odi.12423

28. Lopez-Jornet P, Cayuela CA, Tvarijonaviciute A, Parra-Perez F, Escribano D, Ceron J. Oral lichen planus: salival biomarkers cortisol, immunoglobulin A, adiponectin. J Oral Pathol Med. 2016 Mar;45(3):211-7. https://doi.org/10.1111/jop.12345

29. Panjwani S, Bagewadi A, Keluskar V, Malik R, Rai S, Misra D. Estimation and comparison of levels of salivary nitric oxide in patients with oral lichen planus and controls. Int J Prev Med. 2013 Jun; $4(6): 710-4$.

30. Sunitha M, Shanmugam S. Evaluation of salivary nitric oxide levels in oral mucosal diseases: A controlled clinical trial. Indian J Dent Res. 2006 Jul-Sep;17(3):117-20. https://doi.org/10.4103/0970-9290.29878

31. Jagtap K, Baad RK. Estimation of salivary nitric oxide in recurrent aphthous ulcer and oral lichen planus patients with its clinical significance. J Contemp Dent Pract. 2012 Sep;13(5):623-6. https://doi.org/10.5005/ip-journals-10024-1198

32. Khan KS, Kunz R, Kleijnen J, Antes G. Five steps to conducting a systematic review. J R Soc Med. 2003 Mar;96(3):118-21. https://doi.org/10.1177/014107680309600304

33. Moher D, Liberati A, Tetzlaff J, Altman DG. Preferred reporting items for systematic reviews and meta-analyses: the PRISMA statement. Ann Intern Med. 2009;151(4):264-9.

34. Howick J, Chalmers I, Glasziou PG, Heneghan C, Liberati A, Moschetti I et al. The Oxford levels of evidence 2. Oxford: Oxford Centre for Evidence-Based Medicine; 2011. 
35. Dan H, Liu W, Wang J, Wang Z, Wu R, Chen Q et al. Elevated IL-10 concentrations in serum and saliva from patients with oral lichen planus. Quintessence Int. 2011 Feb;42(2):157-63.

36. Zhang Y, Liu W, Zhang S, Dan H, Lu R, Wang F et al. Salivary and serum interleukin-18 in patients with oral lichen planus: a study in an ethnic Chinese population. Inflammation. 2012 Apr;35(2):399-404 https://doi.org/10.1007/s10753-011-9327-3

37. Wang K, Miao T, Lu W, He J, Cui B, Li J et al. Analysis of oral microbial community and Th17-associated cytokines in saliva of patients with oral lichen planus. Microbiol Immunol. 2015 Mar;59(3):105-13. https://doi.org/10.1111/1348-0421.12232

38. Malekzadeh H, Robati M, Yousefimanesh H, Ghafourian Boroujerdnia M, Nadripour R. Salivary Interferon Gamma and Interleukin-4 levels in patients suffering from oral lichen planus. Cell J. 2015;17(3):554-8.

39. Liu WZ, He MJ, Long L, Mu DL, Xu MS, Xing X et al. Interferon- $\gamma$ and interleukin- 4 detected in serum and saliva from patients with oral lichen planus. Int J Oral Sci. 2014 Mar;6(1):22-6. https://doi.org/10.1038/ijos.2013.74

40. Pezeli-Ribaric S, Prso IB, Abram M, Glazar I, Brumini G, Simunovic-Soskic M. Salivary levels of tumor necrosis factor-alpha in oral lichen planus. Mediators Inflamm. 2004 Apr;13(2):131-3. https://doi.org/10.1080/09629350410001688530

41. Abdel-Haq A, Kusnierz-Cabala B, Darczuk D, Sobuta E, Dumnicka P, Wojas-Pelc A et al. Interleukin- 6 and neopterin levels in the serum and saliva of patients with Lichen planus and oral Lichen planus. J Oral Pathol Med. 2014 Nov;43(10):734-9. https://doi.org/10.1111/jop.12199

42. Tao X, Li C, Rhodus NL, Xia J, Yang X, Cheng B. Simultaneous detection of IFN-gamma and IL-4 in lesional tissues and whole unstimulated saliva from patients with oral lichen planus. J Oral Pathol Med. 2008 Feb;37(2):83-7. doi: 10.1111/i.1600-0714.2007.00593.x.

43. Jeong SH, Na HS, Park SH, Ahn YW, Chung J. Topical sulfasalazine for unresponsive oral lichen planus. Quintessence Int. 2016 Apr;47(4):319-27.

44. Mozaffari HR, Ramezani M, Mahmoudiahmadabadi M, Omidpanah N, Sadeghi M. Salivary and serum levels of tumor necrosis factor-alpha in oral lichen planus: a systematic review and meta-analysis study. Oral Surg Oral Med Oral Pathol Oral Radiol. 2017 Sep;124(3):e183-9. https://doi.org/10.1016/j.0000.2017.06.117

45. Rödström PO, Jontell M, Hakeberg M, Berggren $U$, Lindstedt $G$. Erosive oral lichen planus and salivary cortisol. J Oral Pathol Med. 2001 May;30(5):257-63. https://doi. org/10.1034/j.1600-0714.2001.300501.x

46. Girardi C, Luz C, Cherubini K, de Figueiredo MA, Nunes ML, Salum FG. Salivary cortisol and dehydroepiandrosterone (DHEA) levels, psychological factors in patients with oral lichen planus. Arch Oral Biol. 2011 Sep;56(9):864-8. https://doi.org/10.1016/i.archoralbio.2011.02.003

47. Shah B, Ashok L, Sujatha GP. Evaluation of salivary cortisol and psychological factors in patients with oral lichen planus. Indian J Dent Res. 2009 Jul-Sep;20(3):288-92. https://doi.org/10.4103/0970-9290.57361

48. Nadendla LK, Meduri V, Paramkusam G, Pachava KR. Association of salivary cortisol and anxiety levels in lichen planus patients. J Clin Diagn Res. 2014 Dec;8(12):ZC01-03.

49. Karthikeyan P, Aswath N. Stress as an etiologic co-factor in recurrent aphthous ulcers and oral lichen planus. J Oral Sci. 2016;58(2):237-40. https://doi.org/10.2334/josnusd.15-0610

50. Nosratzehi T, Fateme AK, Saeedeh SE. The evaluation of psychological factor and salivary cortisol and IgA levels in patients with oral lichen planus. Zahedan J Res Med Sci. 2014;16(7):4.

51. Ohashi M, Iwase M, Nagumo M. Elevated production of salivary nitric oxide in oral mucosal diseases. J Oral Pathol Med. 1999 Sep;28(8):355-9. https://doi.org/10.1111/i.1600-0714.1999.tb02053.x

52. Tvarijonaviciute A, Aznar-Cayuela C, Rubio CP, Ceron JJ, López-Jornet P. Evaluation of salivary oxidate stress biomarkers, nitric oxide and $\mathrm{C}$-reactive protein in patients with oral lichen planus and burning mouth syndrome. J Oral Pathol Med. 2017 May;46(5):387-92. https://doi.org/10.1111/jop.12522

53. Slominski A, Wortsman J. Self-regulated endocrine systems in the skin. Minerva Endocrinol. 2003 Jun;28(2):135-43.

54. Slominski A, Pisarchik A, Tobin DJ, Mazurkiewicz JE, Wortsman J. Differential expression of a cutaneous corticotropin-releasing hormone system. Endocrinology. 2004 Feb;145(2):941-50. https://doi.org/10.1210/en.2003-0851

55. Lisa Cheng YS, Jordan L, Gorugantula LM, Schneiderman $E$, Chen HS, Rees T. Salivary interleukin- 6 and -8 in patients with oral cancer and patients with chronic oral inflammatory diseases. J Periodontol. 2014 Jul;85(7):956-65. https://doi.org/10.1902/jop.2013.130320

56. Zhang $Y$, Lin $M$, Zhang S, Wang Z, Jiang L, Shen J et al. NF-kappaB-dependent cytokines in saliva and serum from patients with oral lichen planus: a study in an ethnic Chinese population. Cytokine. 2008 Feb;41(2):144-9. https://doi.org/10.1016/i.cyto.2007.11.004

57. Kaur J, Jacobs R. Proinflammatory cytokine levels in oral lichen planus, oral leukoplakia, and oral submucous fibrosis. J Korean Assoc Oral Maxillofac Surg. 2015 Aug;41(4):171-5. https://doi.org/10.5125/ikaoms.2015.41.4.171

58. Marshall GD Jr, Agarwal SK, Lloyd C, Cohen L, Henninger EM, Morris GJ. Cytokine dysregulation associated with exam stress in healthy medical students. Brain Behav Immun. 1998 Dec;12(4):297-307. https://doi.org/10.1006/brbi.1998.0537

59. Prolo P, Chiappelli F, Cajulis E, Bauer J, Spackman S, Romeo H et al. Psychoneuroimmunology in oral biology and medicine: the model of oral lichen planus. Ann N Y Acad Sci. 2002 Jun;966(1):429-40. https://doi.org/10.1111/j.1749-6632.2002.tb04244.x

60. Clements AD. Salivary cortisol measurement in developmental research: where do we go from here? Dev Psychobiol. 2013 Apr;55(3):205-20. https://doi.org/10.1002/dev.21025

61. Lowenstein CJ, Snyder SH. Nitric oxide, a novel biologic messenger. Cell. 1992 Sep;70(5):705-7. https://doi. org/10.1016/0092-8674(92)90301-R 
62. Looms D, Tritsaris K, Pedersen AM, Nauntofte B, Dissing $S$. Nitric oxide signalling in salivary glands. J Oral Pathol Med. 2002 Nov;31(10):569-84. https://doi.org/10.1034/j.1600-0714.2002.00047.x
63. Wang J, Schipper HM, Velly AM, Mohit S, Gornitsky M. Salivary biomarkers of oxidative stress: a critical review. Free Radic Biol Med. 2015 Aug;85:95-104. https://doi.org/10.1016/j.freeradbiomed.2015.04.005 